\title{
Owner Project Safety Leadership and Explosives Management in a Construction Project in Kashmir
}

\author{
Prof Dr. Paul James \\ Graduate School, Bangkok University \\ Rama 4 Road, Klong-Toey, Thailand \\ Tel: 66-20-350-3500Ｅ-mail: paul.j@bu.ac.th
}

Received: October 11, 2019 Accepted: November 11, 2019 Published: November 18, 2019

doi:10.5296/jss.v5i1.15613ＵRL: http://dx.doi.org/10.5296/jss.v5i1.15613

\begin{abstract}
This is research is focused on the evaluation of Owner Engineer perceptions and its impacts on Explosives management practices and developments related to an Engineering, Procurement and Construction Contract (EPC) Tunnel Construction Project in Kashmir using an interpretive methodology.

The scope for this research was the Owner engineer project team. The population of interest was made up of 13 senior engineers, encompassing a multi-site EPC Tunnel Construction Project. Eleven (11) senior engineers were carefully targeted as a designed sample size.

The research outcomes consisted of three (3) Main Themes - Site Safety; Explosives Management and Security Issues and fourteen (14) sub-themes, with 387 dialogue targets.

The paper addresses a variety of major issues resulting from the analysis of narrative data relating to Owner project safety leaderships and raises determinations of the implications for managing safety at the project sites and in the wider community.
\end{abstract}

Keywords: Safety Management, Construction, Explosives, Security, Tunnel, EPC

\section{Introduction}

This is a study of the failings of project safety leadership and its impacts on an Engineering, Procurement and Construction Contract (EPC) road tunnel construction site and wider/regional security issues in Kashmir. There have been many reported instances of construction project failures (Davidson \& Maguire, 2003; Kivrak \& Arslan, 2008) and Owner project management issues (Winch \& Leiringer, 2015). However, there are few reports where safety issues have been cited that impinge critically on construction site operational capability (Toole, 2002; Aksorn \& Hadikusumo, 2008). 
Project leadership appears to be an essential requirement for managing large, complex projects (Bass, 1999; Richman, 2006). It is considered so important that all certified project managers through the PMI (2017) have developed and utilised the safety concept. However, there is considerable confusion over defining project safety leadership (Read, et al., 2010; Rao, 2007) which appears to entail managing others, developing safety processes and applicable methods in order to establish superior performance (Abeysekera \& McLean, 2001) whilst reducing construction accidents (Clarke and Taylor, 2018). A major task of project leadership is to set direction (King, 2013) and to create the overall safety climate (Hofmann \& Stetzer, 1996; Neal, Griffin and Hart, 2000). These will also be seen by the Project Owner as mandatory through the Contract requirements (Subramani \& Lordsonmillar, 2014) in order to show the effectiveness of internal project safety management through improvements in observable key safety metrics (Cambon, Guarnieri \& Groeneweg, 2005) and overall project performance (Sagar \& Yadav, 2013) as well as being attributed to the scope of the Contractor safety policy requirements (Davies \& Tomasin, 1996).

Project safety leadership focuses on reducing negative safety behaviours (often through transformational leadership - Bass, 1999) as it has received a significant amount of study scrutiny (Avolio, 1999) by helping move resistance to new ideas through effective communication (Mattson, Hellgren \& Göransson, 2015) and personnel engagement (Barling, Loughlin \& Kelloway, 2002). Safe behaviour for all concerned at project sites is therefore a continuing managerial challenge (Zohar, 2002).

Underpinning safety development in complex projects includes close cooperation and leadership through supervisory safety meetings (Lingard \& Rowlinson, 1997; Mahan et al., 2013) and increased application of compliance measures (Clarke, 2006) resulting in safety risk mitigation (Hallowell \& Gambatese, 2009). However, where technical safety developments progress, much is held back by failures of managerial and organisational indifference to safety requirements (Weick, Sutcliffe \& Obstfeld, 1999).

\subsection{Owner Leadership Developments}

For EPC contract projects, most of the risk associated with its construction rests with the Contractor (Molenaar \& Saller, 2003). However, the Project Owner still has a large influence on the safety development at site through imposing contractual conditions (EPC FIDIC, 1999). Consequently, developing Project Owner leadership skills that enhance good safety practices (Huang \& Hinze, 2006) through the application of appropriate safety standards (Toole, 2002) and compliance engagement (Podsakoff et al., 2006) seems to be a logically imposed duty corresponding to the application of effective due diligence practices and contractual requirements (EPC FIDIC, 1999 - S4.1 and S6.7). However, project safety patterns revealed through audits, suggest systemic failures are often the result of poor matches between the contractor project management orientation and what the Project Owner will accept (Hillson, 2003). Consequently, considerable issues arise when the Contractor engages as an agent of the Owner (Cerić, 2015) and reduces the effectiveness of the construction site safety provision (Tam \& Fung, 1998) by directly affecting safety climate conflation (Zahoor et al., 2017) through lack of stakeholder management commitment (Hinze, Thurman \& Wehle, 2013). This places the Project Owner in a position to affect the behaviour 
of less powerful individuals and align their focus and objectives away from the project scope, objectives and delivery requirements and subsequent success (Hussein, Ahmad \& Zidane, 2015; Yang, et al., 2010). However, there is considerable focus of published research relating to safety management studies in general (Keegan \& Hartog, 2004), but there is a significant vacuum investigating the safe use of explosives in construction projects - especially in restive regions.

Consequently, this raises defined issues (Househ, 2011), and creates the context for the research question, in what ways do Project Owner Safety Leadership Behaviour Impact on Project Outcomes

\section{Methodology}

This research orientation is towards the Project Owner engineer staff of a multi-site road tunnel project in Kashmir. Discovering specific Owner engineer perceptions of prominent project leadership issues demands a qualitative inquiry (Hill, Thompson \& Williams, 1997; Walsh, White \& Young, 2008). Consequently, the research focus of Owner engineer staff opinions that reflect authoritive 'knowledge agent' experiences (Benn et al., 2008; Sbaraini et al., 2011) underpinned by significant observations (Sutton \& Austin, 2015). The research engaged a narrow semi-structured interview process underpinned from a subjective knowledge perspective (Kvale, 1996) and an inductive/theory building approach (Glaser \& Strauss, 1967). This methodology is suitable for constructing suitable contextual data outcomes (Qu \& Dumay, 2011) by building richer theory development (Cayla \& Eckhardt, 2007) through components of reflexivity (Malterud, 2001).

A pilot study, with two (2) respondents from the targeted population was carried out and excluded from the main interview process following Maxwell (2013). This examined and informed changes to language and the logic of suitable interview questions to respondents (Kim, 2011) whilst providing a more thorough and thoughtful questioning sequence (James \& James, 2011).

Eleven (11) engineers (only those employed at site) were carefully targeted as a closed final sample - which were all confined within a specifically identified research frame (Ritchie \& Lewis, 2003; Fink, 2000) and were chosen by employing the approach of a closed population of interest (Carman, 1990). Consequently, this research work is focused on the managerial issues raised when conducting project safety activities. This ensures empirical and functional research process adequacy (Spanos, 1990).

All interviews were conducted in English and took approximately one hour (Ward et al., 2015; Sbaraini et al., 2011), and were also recorded with permission (Duranti, 2007; Orb, Eisenhauer \& Wynaden, 2001). Each respondent was interviewed using an identical set of open questions (Gray \& Wilcox, 1995; James, 2014; Kvale, 1996), amended through the use of additional probing questions (Balshem, 1991; Punch, 2014; Meurer, et al., 2007). Each interview was transcribed verbatim - using the qualitative software package NVivo 11 (after Bailey, 2008) and was further returned to each respondent for any assessed changes (Irvine, Drew \& Sainsbury, 2012; Harris \& Brown, 2010). Whole-process validity (Denzin \& Lincoln, 1998) through methodological coherence (Altheide \& Johnson, 1998) was preserved by 


\section{Macrothink

linking the research question to the data results (Stenbacka, 2001).

Each interview transcription was manually scrutinised during which discernible codes surfaced (Dey, 2005) providing an initial underpinning of the thematic analysis (Glaser, 1992; Walsh, White \& Young, 2008; Charmaz, 2006). Consequently, no narrative was left uncoded (Rubin \& Rubin, 2005; James \& James, 2011) and the complete outcome fully represented the respondent's views through cyclic-progressive coding-sequences (Buston, 1997; James, 2015; Seale \& Silverman, 1997). These identified themes were subsequently analysed and this established robust rigour where site practices and experience were pursued in the "public interest' (Branston, Cowling \& Sugden, 2006; Matei \& Drumasu, 2015). Validity was increased using triangulation processes (Onwuegbuzie \& Leech, 2007) associated with media from a variety of sources (Harwood \& Garry, 2003; Ryan \& Bernard, 2003) such as project safety reports. The narrative raised from applying the methodological approach (James \& James, 2011), was based on applying 'credibility' (Johnson, 1997) and 'dependability' (Lincoln \& Guba, 1985) in place of 'reliability' (Strauss \& Corbin, 1990).

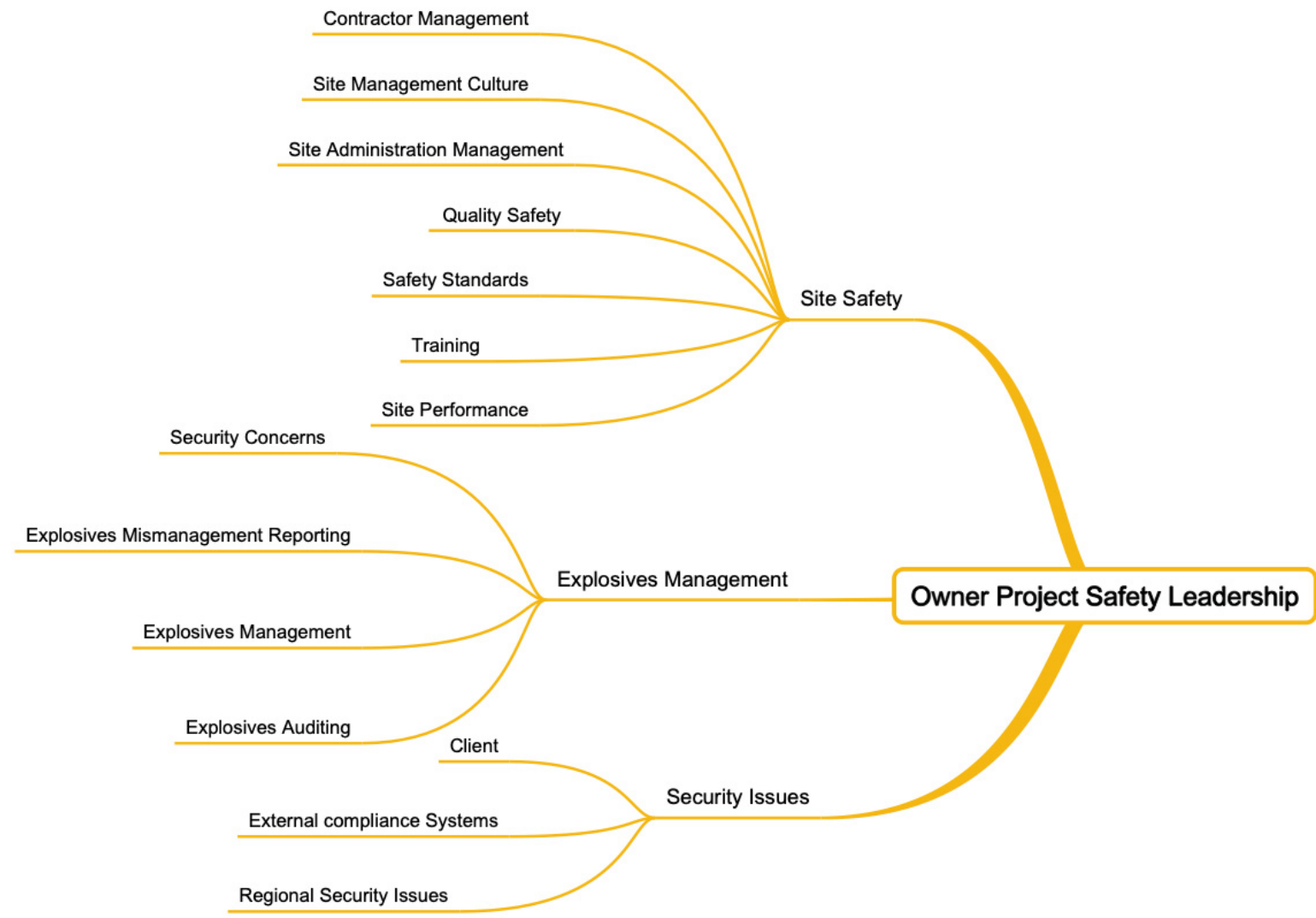

Figure 1. Research Outcomes

\subsection{Illustration of Research Outcomes}

The research outcomes can be seen in Figure 1 above. These outcomes are also illustrated with respondent citations and discussion targets below in Table 1 and consists of three (3) Main-Themes - Site Safety; Explosives Management and Security Issues; and fourteen (14) 
sub-themes - with 387 dialogue targets.

Table 1. Research question, themes and discussion targets

Research Question

In what ways do Project Owner Safety Leadership Behaviour Impact on Project Outcomes?

\begin{tabular}{|c|c|c|c|}
\hline Main-Themes & Sub-Themes & $\begin{array}{l}\text { Respondent } \\
\text { Citations }\end{array}$ & $\begin{array}{l}\text { Discussion } \\
\text { Targets }\end{array}$ \\
\hline \multirow[t]{8}{*}{$\underline{\text { Site Safety }}$} & Contractor Management & 7 & 35 \\
\hline & Site Management Culture & 3 & 26 \\
\hline & Site Administration Management & 11 & 21 \\
\hline & Quality Safety & 9 & 33 \\
\hline & Safety Standards & 1 & 32 \\
\hline & Training & 5 & 30 \\
\hline & Site Performance & 2 & 24 \\
\hline & & Theme Total & 201 \\
\hline \multirow{5}{*}{$\begin{array}{l}\text { Explosives } \\
\text { Management }\end{array}$} & Explosives Management & 4 & 27 \\
\hline & Explosives Auditing & 6 & 36 \\
\hline & Explosives Mismanagement Reporting & 9 & 38 \\
\hline & Security Concerns & 2 & 23 \\
\hline & & Theme Total & 124 \\
\hline \multirow[t]{4}{*}{$\underline{\text { Security Issues }}$} & Owner & 10 & 21 \\
\hline & External compliance Systems & 8 & 23 \\
\hline & Regional Security Issues & 4 & 18 \\
\hline & & Theme Total & 62 \\
\hline
\end{tabular}

\section{Results}

The results are presented below, where the respondent's voice is revealed through the ad-verbatim dialogue (Cassell \& Symon, 2004). The reporting format is informed by Gonzalez (2008) and Daniels, et al. (2007), where each Main-theme is examined contiguous to each respective sub-theme. These are stated as below:

Main Theme $-\underline{\text { Site Safety }}$

In terms of Contractor Management, this is typified by one respondent (7) who suggested that, ... They keep telling us that the van [explosives] is in transit. But we know that the van is just parked up on the road. They keep telling us lies as it is obvious that the Contractor PM is 
getting his orders not to cooperate with the Engineer. It is a difficult situation, one that is out of control, because we don't know who is hiding any explosives here..."

In terms of Site Management Culture, this is typified by one respondent (3) who offered that,...There is no doubt that they [Contractor] are deceitful and do not want any form of scrutiny from us. The Contractor hides everything. It is unclear why they do it, but you can see that their behaviour is very difficult for us. Their attitude shows they are not very open, and they do not like that their activities are reported on or photographed or videoed..."

In terms of Site Administration Management, this is typified by one respondent (11) who indicated that, "...We have many incidents each week, where the Contractor PM is called to site. He doesn't like it, but he mostly comes. He has been red-carded many times, but he does nothing. I wonder why? They do not follow any safety procedure or code. There is a lot of collusion. I wonder why?..."

In terms of Quality Safety, this is typified by one respondent (9) who intimated that, “...I have inspected their labs, but it is all for show. No one here does anything according to any quality or safety standards. No one. This is very dangerous for the project. They do not show any interest in creating any standard of work and this will lead to major failures..."

In terms of Safety Standards, this is typified by one respondent (1) who suggested that, "...It is so disappointing that the Owner totally ignored all the safety reports and meetings. His purpose was so different, it seemed he had other motives. There was a lot of evidence of systemic safety failure at site. Too many for normal. We told the Owner many times, followed good safety practices and it didn't get us anywhere. They are just criminals. We know that now..."

In terms of Training, this is typified by one respondent (5) who advocated that, "...No one is trained in managing explosives at site. We asked many times for all their training certificates - for all management and critical workers, but they didn't send us any back. No management, and even the Exploder seems to be very untrained. This is not good..."

In terms of Site Performance, this is typified by one respondent (2) who specified that, "...We have spent so much time on explosives issues, that monitoring the crucial construction project is very difficult, if not impossible. This will lead to delays and overruns..."

\section{Main Theme - Explosives Management}

In terms of Explosives Management, this is typified by one respondent (4) who advised that, "...It is conceivable that because they won't let us properly oversee the management of explosives use on site, that these very dangerous materials will get into the wrong hands. That's the risk. Much of the documentation is wrong. The legal stuff just isn't there. It is like being in the wild west. They do anything they like, and no one can stop them. I believe the mismanagement where there is a strong link to the missing explosives and stuff..."

In terms of Explosives Auditing, this is typified by one respondent (6) who indicated that, “...They are out of control. They won't let you inspect the vans, the explosives magazine nor review their explosives accounting system. No licenses are available. It is a very dangerous place. We are professionals. They behave like donkeys. It is only a matter of time before there 
is a serious incident. They continue to stand in our way, the Owner is told, and they still block us. Someone will get killed..."

In terms of Explosives Mismanagement Reporting, this is typified by one respondent (9) who intimated that, "...In one month, there were 776 safety violations reported to the Owner; 266 explosives management violations - 42 so serious that the site should have been closed down through red-cards and wasn't; and a review carried out; 88 explosives Van violations; 68 Red-Cards to personnel (management and supervisors) and 8 Red-Cards for the site as a whole. All reported to the Owner. What can you do with a Owner like this? - especially now that we know that huge amounts of explosives has gone missing..."

In terms of Security Concerns, this is typified by one respondent (2) who advocated that, “...I have seen them physically blocking the engineer trying to make sure that all the explosives are accounted for. Even the police stop us. They say one thing, organise another. I have even found numerous occasions of explosives being taken in work boxes out of the tunnel and then down the road and off-site. How can this happen?..."

\section{Main Theme - $\underline{\text { Security Issues }}$}

In terms of Owner, this is typified by one respondent (10) who determined that, "...The project Owner knows about these explosives issues. I have seen very comprehensive reports made to the Owner. They know. But they don't do anything about it. Explosives and dets would go missing - even when the [explosives] vans are parked at a police station..."

In terms of External Compliance Systems, this is typified by one respondent (8) who suggested that, “...They are useless here. No power. The Owner is in charge and defers to the Contractor. The Owner blocked the explosives inspectorate from being reported to and certainly wouldn't want them to come here. No external audits will ever be done, even after many deaths and accidents..."

In terms of Regional Security Issues, this is typified by one respondent (4) who intimated that, "...You can inform them - the police, government agencies and such, but they will call the Contractor, and he will stop them coming. Even for explosives accidents, no one interferes. This is a restrictive zone. What do you expect?..."

\section{Discussion}

The discussion below uses an engaged analysis resulting from reframing the stated narrative (Popay et al., 2006) through robust induction (Morse, 2018).

For most complex project construction sites that use explosives, one of the main safety requirements is the focus is on the most effective use of explosives coupled with managing risk and safety requirements in a standards-oriented culture (Machfudiyanto et al., 2017). However, the outcome suggests clearly that much effort was spent, by the contractor, on hiding their activities associated with explosives use at site, and in the supply chain across delivery chains to the explosive's manufacturer. Consequently, this outcome supports the notion that where management and Owner do not support the working environment and safety practices, they do not develop or improve (Lingard \& Rowlinson, 1997). 


\subsection{Site Safety}

\section{Safety Leadership in Projects constructing in security sensitive sites}

The project requires the development of a rigorous safety culture and that systemic safety failures in such environments are linked to systemic inaction, ignoring or even deliberate isolation (IAEA Safety Standards, 2012). Effective on-site project safety leadership is clearly lacking, reflecting a fatalist culture (Daniellou, Simard \& Boissières, 2010) postulating a hinderance to good project success (Zhao, Hwang \& Low, 2015). This, therefore, requires an operational safety-culture change (Senior \& Fleming 2006; Englund, Graham \& Dinsmore, 2003). This is principally required in construction projects that use explosives and surrounded by a security sensitive region, as this materially provides fundamental operational constraints related to security, site safety and protection of the public (BTS, 2013; PMI, 2017). However, it also requires the Owner to be aware of the need to utilise high levels of safety and security awareness (Gao et al., 2016) and apply appropriate precautions in order to ensure safety at site. This suggests that security awareness training should be carried out with all stakeholders and integrated into the regional emergency plan (Hotchkiss, 2018).

The data indicated that no Contractor safety audit documents were ever recorded as being conducted, sanctioned by the Engineer or officially recognised by the Owner. This indicates clearly that the level of engagement in site safety management is considered immature, weak, lacks organisational learning and does not demonstrate trustworthiness and accountability (Gardner et al., 2005) or any worker level of safety performance (Raines, 2011). Thus, the poor leadership climate is supported by a "no document" doctrine, resulting in lack of appropriate explosives identification and traceability evidence (James, 2005; ER2014, 2014; ISO 9001:2015a). This means that the construction site was out-of-control as far as quality and safety was concerned, as there is a demonstrated lack of appropriate project planning engagement (PMI, 2017). Further, since there was no quality management certification to ISO 9001 (ISO 9001: 2015b) or any other management standard, there is no traceability relating to accountability or due diligence (James, 2009; Flyvbjerg, 2012) or resulting explosives use at site or elsewhere (Commission Directive, 2008).

The Contractor as a partner with the Owner in the project contract, have both failed in their contractual duties to provide appropriate levels of safety as required under an EPC contract (Huse, 2002; EPC FIDIC, 1999 - s4.8). To help mitigate the raised safety issues, contractor site management should develop and apply substantial and realistic safety plans (Senouci, Al-Abbadi \& Eldin, 2015; HSG65, 2013). In terms of engaging independent authorities responsible for reviewing critical aspects of site operations, the Contractor should adopt appropriate risk management plans (Flanagan \& Norman, 1999; Damnjanovic \& Reinschmidt, 2020) and risk registers (Barry, 1995; Patterson \& Neailey, 2002).

\subsection{Explosives Management}

The data suggests unequivocally, that the Contractor did not provide the supervising Engineer with an explosives management plan and derived a way to exploit the need for the use of explosives at site without carrying out due diligence. This created a weakened leadership safety management culture (Kelloway, Mullen \& Francis, 2006) which needs to be improved 
(Senouci, Al-Abbadi \& Eldin, 2015) as it reflected serious and significant on-site safety failures (Sherratt, 2016) and demonstrated non-compliance to appropriate standards and legislation (BS 6164, 2011; The Explosives Act, 1884; The Explosives Rules, 2008). Consequently, it would appear that the contractor management did not give serious consideration to how explosives was used at site, did not have an operational explosives management plan, nor to ensure how explosives audit trails (traceability - Pryke, 2009) were effective (ER2014, 2014; Commission Directive, 2008). As a consequence of this, the data indicated that there were many instances of explosives being picked up, handled and moved by personnel not certified to do this, and many incidents where explosives and detonators were left abandoned on waste-dumping grounds - contrary to operating contractual standards/legislation (BS 5607:2017; The Explosives Rules, 2008).

Further, there were considerable issues raised from the data that indicated that no senior managers at the project site (Contractor or Owner) had any explosives management experience or were certified by the local/regional authorities to manage or handle explosives. This was an obvious safety management issue, which leads to enhanced risk (Caldwell, 2017) and breaches good safety practices (BS 6164, 2011). As was the lack of an explosive's magazine licence and the lack of a certified recipient competent authority and/or an 'acquire and keep' certificate - contrary to licencing legislation and standards (The Explosives Act, 1884; The Explosives Rules, 2008; and for example, Explosives Regulations (2014-UK) (representing best practice).

Further, this suggests a clear practice directed towards allowing non-certified individuals to handle explosives on and off-site. Whilst good management practices would be the primary requirement in $1^{\text {st }}$ World Countries, the data clearly suggests a massive and systemic failure of the wider authorities to allow such mistakes to occur - such as the Chief Controller of Explosives (The Explosives Act, 1884; The Explosives Rules, 2008). Further, since the safety issues were monitored and reported for over 18 months, the authorities, through the Chief Controller of Explosives, could also be deemed to be culpable in the serious outcomes of the reported consistent breaches of explosives management legislation, standards, codes and protocols.

\subsection{Security Issues}

The raised security issues showed that the site was considered "open" in that anyone from the local area, could and did, frequent the site during and after-hours. Leadership practices protecting the site and workers, did not play a role in the "normal" safety process of the works (Hayes \& Kotwica, 2013) and appears to be ineffective and weak (Toole, 2002). This is contrary to best practices for mountainous construction sites - and especially on those project sites using explosives (Elbeltagi, Hegazy \& Eldosouky, 2004). Another aspect of the reported site safety mismanagement was the effect of the lack of systematic safety performance on site personnel and off-site on local inhabitants (Jackson et al., 2011; Thomas, 2012). The responsibility to develop site safety leadership needs to be driven from top down (El-Reedy, 2011) and made much more visible with the safety intent clearly revealed (Sherratt, 2016). It would also appear that security personnel were not trained in helping to secure the site and did not take their responsibilities seriously as vehicles and outside 
personnel (including sub-contractors) accessed the site without formal approval or security arrangements resulting from lack of communication, coordination and/or managerial safety intent (Dekker, 2012).

The Contractor lacked business intelligence and business continuity plan regarding explosives management at site (MSH, 2017), which is considered highly contrary to effective site planning and implementation requirements (Fennelly \& Perry, 2014).

However, with the lack of appropriate site security standards, it is not beyond reasonable thought that external security incidents - beyond the site purview, could occur. Given the restive state of the regional Kashmir environment, it is perhaps vaguely difficult to accept that such practices could intensify severe security issues that are now present within the Kashmir region.

\section{Conclusions}

The Project Owner appears to have relinquished their responsibility under the Contract to lead appropriate safety developments at site (EPC FIDIC, 1999) reflecting the first term in the Owner Contractual duty for this project (Concession Agreement, 2013 - Contract). Thus, EPC contracts do not appear to be effective, if the Contractor can ignore the Project Owner's engineer, and the EPC FIDIC contract (1999) is thus an ineffective contractual orientation for tunnelling projects when the Contractor appears to think that there is no Owner contractual governance requirements.

The project has failed to meet its objectives and is now stopped. It is difficult to conclude that mismanagement of explosives at the construction site were involved in restive patterns of engagement with the security forces, and that the mismanagement was solely attributed to negligence. However, considering the length of time of the critical safety assessment, their depth of inquiry and the rigorous levels of safety auditing and consequent reporting (Caldwell, 2017), it is also difficult to ignore this possible connection.

Reporting safety performance of accident rates and type, including deaths and severe injury appears to be meaningless in Kashmir, as such incident go unnoticed by the authorities and this further creates the issue of culpability of overseeing authorities in masking such rates and incidences. Consequently, the Project Owner cannot absolve itself of the responsibility for leading safety by ignoring on-site practices in the hope of increased production.

The conflation of inadequate contractor supervision of explosives on site and Project Owner disposition not to recognise safety failures means that the motivation of personnel (within and outside the project) to consistently disrupt the attempts of the Owner's engineer to carry out their safety duties under the contract, may also have serious consequences for the wider restive community.

The failure of project safety leadership at site by both the Contractor and specifically the Project Owner, may affect more than just site safety, as the possibility that explosives from site may have been used by unknown actors that have affected the security of the Kashmir region. This, therefore, has implications for innocent members of the public, as well as for the security of the region and beyond. However, these types of incidents have occurred 
previously in a separate, Pakistan construction project that also used explosives, resulting in similar outcomes (James, 2014). Consequently, the lack of security surrounding explosives management, reinforced by regional police and the Project Owner, therefore has raised immense issues that can only now be solved at a much wider level. This has left the site consistently unsafe and such lapses in safety leadership has had a wholly negative effect on the region as a consequence, which may also have wider, more dire consequences (The Guardian, 2019).

\section{References}

Abeysekera, V., \& McLean, C. (2001). Project Success and Relationships from a Stakeholder Perspective. Proceedings of the 17th Annual ARCOM Conference (pp. 485-494). Salford, UK, 5-7 September. Association of Researchers in Construction Management.

Aksorn, T., \& Hadikusumo, B. (2008). Critical success factors influencing safety program performance in Thai construction projects. Safety Science, 46, 709-727. https://doi.org/10.1016/j.ssci.2007.06.006

Altheide, D., \& Johnson, J. (1998). Criteria for assessing interpretive validity in qualitative research. In N. Denzin, \& Y. Lincoln (Eds.), Collecting and interpreting qualitative materials (pp. 283-312). Thousand Oaks, CA, USA: Sage Publications.

Avolio, B. (1999). Full leadership development: Building the vital forces in organizations. Newbury Park, CA: Sage Publications.

Bailey, K. (2008). Methods of Social Research. New York, USA: The Free Press.

Balshem, M. (1991). Cancer, Control and Causality: Talking about Cancer in a Working-Class Community. American Ethnologist, 18(1), 152-172. https://doi.org/10.1525/ae.1991.18.1.02a00070

Barling, J., Loughlin, C., \& Kelloway, K. (2002). Development and Test of a Model Linking Safety-Specific Transformational Leadership and Occupational Safety. Journal of Applied Psychology, 87(3), 488-496. https://doi.org/10.1037//0021-9010.87.3.488

Barry, L. (1995). Assessing risk systematically. Risk Management, 42, 12-17.

Bass, B. (1999). Two decades of research and development in transformational leadership. European Journal of Work and Organizational Psychology, 8(1), 9-32. https://doi.org/10.1080/135943299398410

Benn, N., Buckingham, S., Domingue, J., \& Mancini, C. (2008). Ontological Foundations for Scholarly Debate Mapping Technology. In 2nd International Conference on Computational Models of Argument (COMMA '08), Toulouse, France.

Branston, J., Cowling, K., \& Sugden, R. (2006). Corporate Governance and the Public Interest. International Review of Applied Economics, 20(2), 189-212. https://doi.org/10.1080/02692170600581110

BS 6164. (2011). Code of practice for health and safety in tunnelling in the construction industry.

London,

UK:

BSI. 
https://shop.bsigroup.com/ProductDetail?pid=000000000030218916

BS 5607. (2017). Code of practice for the safe use of explosives in the construction industry. BSI, London, UK. https://shop.bsigroup.com/ProductDetail?pid=000000000030341836

BTS. (2010). Specification for Tunnelling. London, UK: Thomas Telford Publishing.

Buston, K. (1997). NUD*IST in action: its use and its usefulness in a study of chronic illness in young people. Sociological Research Online, 2(3), 1-13. https://doi.org/10.5153/sro.89

Caldwell, C. (2017). Sustainable Improvements in Environment Safety and Health. FL, USA: CRC Press, Boca Raton.

Cambon, J., Guarnieri, F., \& Groeneweg. J. (2005). Towards a new tool for measuring safety management systems performance. In E. Rigaud, \& E. Hollnagel (Eds.), Proceedings of the Second Resilience Engineering Symposium (pp. 53-62). 8-10 November 2006, Antibes-Juan-les-Pins, France, Mines Paris, Les presses, Paris.

Carman, J. (1990). Consumer Perceptions of Service Quality: An Assessment of the SERVQUAL Dimensions. Journal of Retailing, 66(1), 33-55.

Cassell, C., \& Symon, G. (2004). Essential Guide to Qualitative Methods in Organizational Research. London, UK: Sage Publications.

Cayla, J., \& Eckhardt, G. (2007). Asian Brands without Borders: Regional Opportunities and Challenges. International Marketing Review, 24(4), 444-456. https://doi.org/10.1108/02651330710761017

Cerić, A. (2015). Trust in Construction Projects. London, UK: Routledge.

Charmaz, K. (2006). Constructing Grounded Theory: A Practical Guide through Qualitative Analysis. London, UK: Sage Publications.

Clarke, S. (2006). The relationship between safety climate and235 safety performance: A meta- analytic review. Journal of Occupational Health Psychology, 11(4), 315-327. http://doi.org/10.1037/1076-8998.11.4.315

Clarke, S., \& Taylor, I. (2018). Reducing workplace accidents through the use of leadership interventions: A quasi-experimental field study. Accident Analysis \& Prevention, 121, 314-320. https://doi.org/10.1016/j.aap.2018.05.010

Commission Directive. (2008). 2008/43/EC, L 94/8, 4th April. [Online] Available: https://eur-lex.europa.eu/LexUriServ/LexUriServ.do?uri=OJ:L:2008:094:0008:0012:EN:PDF (August 12, 2019).

Concession Agreement. (2013). Concession Agreement \& Schedules (Vol. 1). Border Roads Organisation, Ministry of Road, Transport \& Highways, 30 ${ }^{\text {th }}$ April 2013.

Damnjanovic, I., \& Reinschmidt, K. (2020). Data Analytics for Engineering and Construction Project Risk Management. Cham, Switzerland: Springer.

Daniellou, F., Simard, M., \& Boissières, I. (2010). Facteur Humains et Organisationnels de la sécurité industrielle: un état de l'art. Cahiers de la Sécurité Industrielle, Feb 2010. 
Daniels, J., Bradley, M., Cramer, D., Winkler, A., Kinebrew, K., \& Crockett, D. (2007). The Successful Resolution of Armed Hostage/Barricade Events in Schools: A Qualitative Analysis. Psychology in the Schools, 44(6), 601-613. https://doi.org/10.1002/pits.20250

Davidson, R., \& Maguire, M. (2003). Ten most common causes of construction contractor failures. Journal of Construction Accounting and Taxation, January/February, 35-37.

Davies, V., \& Tomasin, K. (1996). Construction Safety Handbook. London, UK: Thomas Telford Publishing.

Dekker, S. (2012). Just Culture: Balancing Safety and Accountability. FL, USA: CRC Press: Boca Raton.

Dey, I. (2005). Qualitative data analysis. London, UK: Routledge.

Denzin, N., \& Lincoln, Y. (1998). Strategies of Qualitative Inquiry. London, UK: Sage Publications.

Duranti, A. (2007). Transcripts, like Shadows on a Wall. Mind, Culture, and Activity, 13(4), 301-310. https://doi.org/10.1207/s15327884mca1304_3

Elbeltagi, E., Hegazy, T., \& Eldosouky, A. (2004). Dynamic Layout of Construction Temporary Facilities Considering Safety. Journal of Construction Engineering and Management, 130(4), 534-541. https://doi.org/10.1061/(ASCE)0733-9364(2004)130:4(534)

El-Reedy, M. (2011). Construction Management for Industrial Projects. Salem, MA, USA: Wiley-Scrivener.

Englund, R., Graham, R., \& Dinsmore, P. (2003). Creating the Project Office. Joosey-Bass: San Francisco, USA.

EPC FIDIC. (1999). Conditions of Contract for EPC/Turnkey Projects. International Federation of Consulting Engineers (FIDIC). Geneva, Switzerland: World Trade Center II.

ER2014. (2014). The Explosives Regulations 2014, No. 1638, Part 10-12, (UK). [Online] Available: http://www.legislation.gov.uk/uksi/2014/1638/made (July 19, 2019).

Explosives Regulations. (2014). [Online] Available: http://www.legislation.gov.uk/uksi/2014/1638/schedule/5/made (September 4, 2019).

Fennelly, L., \& Perry, M. (Eds). (2014). The Handbook for School Safety and Security. Elsevier: Oxford, UK.

Fink, A. (2000). The Role of the Researcher in the Qualitative Research Process. A Potential Barrier to Archiving Qualitative Data. Forum: Qualitative Social Research, 1(3), article 4. [Online] Available: http://nbn-resolving.de/urn:nbn:de:0114-fqs000344 (September 7, 2019).

Flanagan, R., \& Norman, G. (1999). Risk Management and Construction. Blackwell Science: London, UK.

Flyvbjerg, B. (2012). Quality control and due diligence in project management: Getting decisions right by taking the outside view. International Journal of Project Management, 31(5), 760-774. https://doi.org/10.1016/j.ijproman.2012.10.007 
Gao, R., Chan, A., Utama, W., \& Zahoor, H. (2016). Multilevel Safety Climate and Safety Performance in the Construction Industry: Development and Validation of a Top-Down Mechanism. International Journal of Environmental Research and Public Health, 13(11), 1100. https://doi.org/10.3390/ijerph13111100

Gardner, W., Avolio, B., Luthans, F., May, D., \& Walumbwa, F. (2005). Can you see the real me? A self-based model of authentic leader and follower development. The Leadership Quarterly, 16(3), 343-372. https://doi.org/10.1016/j.leaqua.2005.03.003

Glaser, B. (1992). Basics of Grounded Theory Analysis. Mill Valley, CA, USA: Sociology Press.

Glaser, B., \& Strauss, A. (1967). The Discovery of Grounded Theory: Strategies for Qualitative Research. Chicago: Aldine.

Gonzalez, C. (2008). Conceptions of, and approaches to, teaching online: A study of lecturers teaching postgraduate distance courses. Higher Education, 57(3), 299-314. https://doi.org/10.1007/s10734-008-9145-1

Gray, J., \& Wilcox, B. (1995). Good Schools, Bad Schools. Milton Keynes, UK: Open University Press.

Hallowell, M., \& Gambatese, J. (2009). Construction Safety Risk Mitigation. Journal of Construction Engineering and Management, 135(12), 1316-1323. https://doi.org/10.1061/(ASCE)CO.1943-7862.0000107

Harris, L., \& Brown, G. (2010). Mixing interview and questionnaire methods: Practical problems in aligning data. Practical Assessment, Research and Evaluation, 15(1), 1-19.

Harwood, T., \& Garry, T. (2003). An Overview of Content Analysis. The Marketing Review, 3(4), 479-498. https://doi.org/10.1362/146934703771910080

Hayes, B., \& Kotwica, K. (2013). Nine Practices of the Successful Security Leader. Elsevier: Oxford, UK.

Hill, C., Thompson, B., \& Williams, E. (1997). A guide to conducting consensual qualitative research. The Counseling Psychologist, 25(4), 517-572. https://doi.org/10.1177/0011000097254001

Hillson, D. (2003). Assessing Organizational Project Management Capability. Journal of Facilities Management, 2(3), 298-311. https://doi.org/10.1108/14725960410808276

Hinze, J., Thurman, S., \& Wehle, A. (2013). Leading Indicators of Construction Safety Performance. Safety Science, 51(1), 23-28. https://doi.org/10.1016/j.ssci.2012.05.016

Househ, M. (2011). Sharing sensitive personal health information through Facebook: the unintended consequences. Studies in Health Technology and Informatics, 169, 616-620. https://doi.org/10.3233/978-1-60750-806-9-616

Hotchkiss, P. (2018). Explosive Threats: The Challenges they Present and Approaches to Countering Them (p. 123). In A. Masys (Eds.), Handbook of Security Science. Springer: Cham, Switzerland. 
Hofmann, D., \& Stetzer, A. (1996). A cross-level investigation of factors influencing unsafe behaviors and accidents. Personnel Psychology, 49(2), 307-339. https://doi.org/10.1111/j.1744-6570.1996.tb01802.x

HSG65. (2013). Managing for health and safety, HSE, UK. [Online] Available: http://www.hse.gov.uk/pubns/books/hsg65.htm (August 11, 2019).

Huang, X., \& Hinze, J. (2006). Owner's role in construction safety. Journal of Construction $\begin{array}{llll}\text { Engineering } \quad \& \quad \text { Management, } & \text { 132(2), }\end{array}$ https://doi.org/10.1061/(ASCE)0733-9364(2006)132:2(164)

Huse, J. (2002). Understanding and Negotiating Turnkey and EPC Contracts. London: Sweet \& Maxwell.

Hussein, B., Ahmad, S., \& Zidane, Y. (2015). Problems Associated with Defining Project $\begin{array}{llll}\text { Success. } \quad \text { Procedia } & \text { Computer } & \text { 940 } & \text { 640 }\end{array}$ https://doi.org/10.1016/j.procs.2015.08.611

IAEA Safety Standards. (2012). Safety Culture in Pre-Operational Phases of Nuclear Power Plant Projects. Safety Reports Series, 74, International Atomic Energy Agency Vienna, Austria.

Irvine, A., Drew, P., \& Sainsbury, R. (2012). “Am I not answering your questions properly?” Clarification, adequacy and responsiveness in semi-structured telephone and face-to-face interviews. Qualitative Research, 13(1), 87-106. https://doi.org/10.1177/1468794112439086

ISO 9001. (2015a). Quality Management Systems - Requirements. S7.1.5.2. ISO, Geneva, Switzerland.

ISO 9001. (2015b). Quality Management Systems - Requirements. SISO, Geneva, Switzerland.

Jackson, T., Artis, S., Hunng, Y., Kim, H., Hughes, C., Kleiner, B., \& Nolden, A. (2011). Safety Critical Incidents among Small Construction Contractors: A Prospective Case Study. The Open Occupational Health \& Safety Journal, 3, 39-47. https://doi.org/10.2174/1876216601103010039

James, P. (2014). Contractor Safety-Related Behaviour: Safety Management Implications of an Explosives Magazine Audit at a Hydropower Project in NW Pakistan. International Journal of Advanced Fire, Explosive, Environment Safety and Disaster Management, 2(1).

James, P. (2015). Social Media Marketing Developments in Private Hospitals in Bangkok. The Internet Journal of Healthcare Administration, 11(1). https://doi.org/10.5580/IJHCA.35596

James, P. (2009). Making Sense of: Quality Standards and Quality Control. Quality Business Books, UK: London, UK.

James, P. (2005). Total Quality Management in Asia: Practices for the 21st Century. Pearson: Singapore.

James, P., \& James, T. (2011). Qualitative Research Methods for Health Services. London, 
UK: Megellan UK Press.

Johnson, B. (1997). Examining the validity structure of qualitative research. Education, $118(3), 282-292$.

Keegan, A., \& Den Hartog, D. (2004). Transformational leadership in a project-based environment: A comparative study. International Journal of Project Management, 22(8), 609-617. https://doi.org/10.1016/j.ijproman.2004.05.005

Kelloay, E., Mullen, J., \& Francis, L. (2006). Divergent effects of transformational and passive leadership on employee safety. Journal of Occupational Health Psychology, 11(1) 76-86. https://doi.org/10.1037/1076-8998.11.1.76

Kim, Y. (2011). The Pilot Study in Qualitative Inquiry: Identifying Issues and Learning Lessons for Culturally Competent Research. Qualitative Social Work, 10(2), 190-206. https://doi.org/10.1177/1473325010362001

King, C. (2013). The Importance of Leadership and Management in Process Safety. American Institute of Chemical Engineers, 32(2), 179-184. https://doi.org/10.1002/prs

Kivrak, S., \& Arslan, G. (2008). Factors causing construction company failure. Building Abroad, October, 297-305.

Kvale, S. (1996). Interviews: An Introduction to Qualitative Research Interviewing. Thousand Oaks: Sage Publications.

Lincoln, Y., \& Guba, E. (1985). Naturalistic Inquiry. Beverly Hills, CA., USA: Sage Publications.

Lingard, H., \& Rowlinson, S. (1997). Behavior-based safety management in Hong Kong's construction industry. Journal of Safety Research, 28(4), 243-256. https://doi.org/10.1016/S0022-4375(97)00010-8

Machfudiyanto, R., Latief, Y., Arifuddin, R., \& Yogiswara, Y. (2017). Identification of safety culture dimesnions based on the implementation of OSH management system in construction company. Procedia Engineering, 171, 405-412. https://doi.org/10.1016/j.proeng.2017.01.350

Mahan, B., Morawetz, J., Ruttenberg, R., \& Workman, R. (2013). Workplace Safety and Health Improvements Through a Labor/Management Training and Collaboration. New Solutions, 23(4), 561-576. https://doi.org/10.2190/NS.23.4.c

Malterud, K. (2001). Qualitative research: standards, challenges, and guidelines. Lancet, 358, 483-488. https://doi.org/10.1016/S0140-6736(01)05627-6

Matei, A., \& Drumasu, C. (2015). Corporate Governance and public sector entities. Procedia Economics and Finance, $4^{\text {th }}$ World Conference on Business, Economics and Management, WCBEM, 26, 495-504.

Mattson, M., Hellgren, J., \& Göransson, S. (2015). Leader communication approaches and patient safety: An integrated model. Journal of Safety Research, 53, 53-62. https://doi.org/10.1016/j.jsr.2015.03.008

Maxwell, J. (2013). Qualitative Research Design: An Interactive Approach. London, UK: 
Sage Publications.

Meurer, W., Frederiksen, S., Majersik, J., Zhang, L., Sandretto, A., \& Scott, P. (2007). Qualitative Data Collection and Analysis Methods: The INSTINCT Trial. Academic Emergency Medicine, 14, 1064-1071. https://doi.org/10.1197/j.aem.2007.05.005

Molenaar, K., \& Saller, B. (2003). Educational needs assessment for design-build project delivery. Journal of Professional Issues in Engineering Education \& Practice, 129(2), 106-114. https://doi.org/10.1061/(ASCE)1052-3928(2003)129:2(106)

Morse, J. (2018). Theoretical Coalescence. A Method to Develop Qualitative Theory. Nursing Research, 67(2), 177-187. https://doi.org/10.1097/NNR.0000000000000263

MSH. (2017). Explosives: Surface storage and management audit - guide. Government of Western Australia, Department of Mines, Industry Regulation and Safety: Perth, Australia.

Neal, A., Griffin, M., \& Hart, P. (2000). The impact of organizational climate on safety climate and individual behavior. Safety Science, 34(1-3), 99-109. https://doi.org/10.1016/S0925-7535(00)00008-4

Onwuegbuzie, A., \& Leech, N. (2007). Sampling Designs in Qualitative Research: Making the Sampling Process More Public. The Qualitative Report, 12(2), 238-254. [Online] Available: https://nsuworks.nova.edu/tqr/vol12/iss2/7_(June 6, 2019).

Orb, A., Eisenhauer, L., \& Wynaden, D. (2001). Ethics in qualitative research. Journal of Nursing Scholarship, 33(1), 93-96. https://doi.org/10.1111/j.1547-5069.2001.00093.x

Patterson, F., \& Neailey, K. (2002). A Risk Register Database System to aid the management of project risk. International Journal of Project Management, 20(5), 365-374. https://doi.org/10.1016/S0263-7863(01)00040-0

PMI. (2017). A Guide to the Project Management Body of Knowledge (6th ed). (PMBOK guide), Project Management Institute: Pennsylvania, USA.

Podsakoff, P., Bommer, W., Podsakoff, N., \& Mackenzie, S. (2006). Relationships between leader reward and punishment behavior and subordinate attitudes, perceptions, and behaviors: A meta-analytic review of existing and new research. Organisational Behavior and Human Decision Processes, 99(2), 113-42. https://doi.org/10.1016/j.obhdp.2005.09.002

Popay, J., Roberts, H., Sowden, A., Petticrew, M., Arai, L., Rodgers, M., ... Duffy, S. (2006). Guidance on the conduct of narrative synthesis in systematic reviews: A product from the ESRC Methods Programme. https://doi.org/10.13140/2.1.1018.4643

Pryke, S. (2009). Construction Supply Chain Management. Wiley-Blackwell Publishing, Chichester, UK.

Punch, K. (2014). Introduction to Social Research: Quantitative and Qualitative Approaches. London, UK: Sage Publications.

Qu, S., \& Dumay, J. (2011). The qualitative research interview. Qualitative Research in Accounting \& Management, 8(3), 238-264. https://doi.org/10.1108/11766091111162070

Raines, M. (2011). Engaging employees - another step in improving safety. Professional 
Safety.

Rao, S. (2007). Safety culture and accident analysis: A socio-management approach based on organizational safety social capital. Journal of Hazardous Materials, 142(3), 730-740. https://doi.org/10.1016/j.jhazmat.2006.06.086

Read, B., Zartl-Klik, A., Veir, C., Samhaber, R., \& Zepic, H. (2010). Safety Leadership that engages the workforce to create sustainable HSE performance. SPE International Conference on Health, Safety and Environment in Oil and Gas Exploration and Production. Rio de Janeiro, Brazil, 1-18. https://doi.org/10.2118/126901-MS

Richman, A. (2006). Everyone wants an engaged workforce how can you create it? Workspan, 49, 36-39.

Ritchie, J., \& Lewis, J. (2003). Qualitative Research Practice: A Guide for Social Science Students and Researchers. London, UK: Sage Publications.

Rubin, H., \& Rubin, I. (2005). Qualitative Interviewing: The Art of Hearing Data. Thousand Oaks, CA, USA: Sage Publications.

Ryan, G., \& Bernard, H. (2003). Techniques to Identify Themes. Field Methods, 15(1), 85-109. https://doi.org/10.1177/1525822X02239569

Sagar, M., \& Yadav, M. (2013). Performance measurement and management frameworks: research trends in the last two decades. Business Process Management Journal, 19(6), 947-971. https://doi.org/10.1108/BPMJ-01-2013-0003

Sbaraini, A., Carter, S., Evans, R., \& Blinkhorn, A. (2011). How to do a grounded study a worked example of a study of dental practices. BMC Medical Research Methodology, 11, 128. https://doi.org/10.1186/1471-2288-11-128

Senior, B., \& Fleming, J. (2006). Organizational Change. Financial Times Prentice Hall: Harlow, UK.

Senouci, A., Al-Abbadi, I., \& Eldin, N. (2015). Safety improvement on building construction sites in Qatar. Procedia Engineering, 504-509. https://doi.org/10.1016/j.proeng.2015.10.102

Sherratt, F. (2016). Unpacking Construction Site Safety. Wiley Blackwell: Chichester, UK.

Spanos, A. (1990). Towards a Unifying Methodological Framework. In Modelling Economic Series: Readings in Econometric Methodology. In C. William \& J. Granger, Readings in Econometric Methodology, Oxford, UK: Clarendon Press.

Stenbacka, C. (2001). Qualitative research requires quality concepts of its own. Management Decision, 39(7), 551-556. https://doi.org/10.1108/EUM0000000005801

Strauss, A., \& Corbin, J. (1990). Basics of Qualitative Research: Grounded Theory, Procedures and Techniques. Newbury Park, Chicago, USA: Sage Publications.

Subramani, T., \& Lordsonmillar, R. (2014). Safety Management Analysis in Construction Industry. International Journal of Engineering Research and Applications, 4(6), 117-120.

Sutton, J., \& Austin, Z. (2015). Qualitative research: data collection, analysis management. 
The Canadian Journal of Hospital Pharmacy, 68(3), 226-231. http://dx.doi.org/10.4212/cjhp.v68i3.1456

Tam, C., \& Fung, I. (1998). Effectiveness of safety management strategies on safety performance in Hong Kong. Construction Management and Economics, 16(1), 49-55. https://doi.org/10.1080/014461998372583

The Explosives Act. (1884). [Online] Available: https://indiacode.nic.in/handle/123456789/2301?locale=en (June 23, 2019).

The Explosives Rules. (2008). The Gazette of India: Extraordinary. 164-325. [Online] Available: https://indiacode.nic.in/handle/123456789/2301?locale=en (August 17, 2019).

The Guardian. (2019). Imran Khan warns UN of potential nuclear war in Kashmir. [Online] Available:

https:/www.theguardian.com/world/2019/sep/26/imran-khan-warns-un-of-potential-nuclearwar-in-kashmir (September 27, 2019).

Thomas, M. (2012). A Systematic Review of the Effectiveness of Safety Management Systems. ATSB Transport Safety Report, Cross-modal Research Investigation, XR-2011-002.

Toole, T. (2002). Construction site safety roles. Journal of Construction Engineering Management, 128(3), 203-210. https://doi.org/10.1061/(ASCE)0733-9364(2002)128:3(203)

Walsh, S., White, K., \& Young, R. (2008). Over-Connected? A Qualitative Exploration of the Relationship between Australian Youth and Their Mobile Phones. Journal of Adolescence, 31(1), 77-92. https://doi.org/10.1016/j.adolescence.2007.04.004

Ward, P., Rokkas, P., Cenko, C., Pulvirenti, M., Dean, N., Carney, S., ... Meyer, S. (2015). A qualitative study of patient (dis)trust in public and private hospitals: the importance of choice and pragmatic acceptance for trust considerations in South Australia. BMC Health Services Research, 15(1), 297-308. https://doi.org/10.1186/s12913-015-0967-0

Weick, K., Sutcliffe, K., \& Obstfeld, D. (1999). Organizing for reliability: Processes of collective mindfulness. In R. Sutton, \& B. Staw (Eds.), Research in Organizational Behavior, 21, 81-123. JAI - An Imprint of Elsevier Science, Elsevier: New York, USA.

Winch, G., \& Leiringer, R. (2015). Owner project capabilities for infrastructure development: A review and development of the "strong owner" concept. International Journal of Project Management, 34(2), 271-281. http://dx.doi.org/10.1016/j.ijproman.2015.02.002

Yang, J., Shen, G., Drew, D., \& Ho, M. (2010). Critical success factors for stakeholder management: Construction practitioners' perspectives. Journal of Construction Engineering and Management, 136(Compendex), 778-786. https://doi.org/10.1061/(ASCE)CO.1943-7862.0000180

Zahoor, H., Chan, A., Utama, W., Gao, R., \& Memon, S. (2017). Determinants of Safety Climate for Building Projects: SEM-Based Cross-Validation Study. Journal of Construction Engineering Management, 143(6), $1-12$. https://doi.org/10.1061/(ASCE)CO.1943-7862.0001298 


\section{Macrothink}

Journal of Safety Studies

ISSN 2377-3219 2019, Vol. 5, No. 1

Zhao, X., Hwang, B., \& Low, S. (2015). Enterprise Risk Management in International Construction Operations. Springer: London, UK.

Zohar, D. (2002). Modifying Supervisory Practices to Improve Subunit Safety: A Leadership-Based Intervention Model. Journal of Applied Psychology, 87(1), 156-163. https://doi.org/10.1037//0021-9010.87.1.156

\section{Copyright Disclaimer}

Copyright for this article is retained by the author(s), with first publication rights granted to the journal.

This is an open-access article distributed under the terms and conditions of the Creative Commons Attribution license (http://creativecommons.org/licenses/by/4.0/) 